\title{
Life Cycle Assessment of Compact Fluorescent and Incandescent Lamps: Comparative Analysis
}

\author{
Erika Elijošiutė, Jolita Balciukevičiūtė and Gintaras Denafas \\ Department of Environmental Engineering, Kaunas University of Technology, Lithuania
}

cross'ref http://dx.doi.org/10.5755/j01.erem.61.3.2425

(received in September, 2012, accepted in September, 2012)

\begin{abstract}
The estimates indicate that the energy consumption by lighting is $20-45 \%$ of a commercial building's and $3-10 \%$ of an industrial plant's total energy consumption. It is more reasonable to use energy efficient lamps such as compact fluorescent lamps (CFLs), consuming only $20 \%$ electricity for the same light output compared with incandescent lamp. The aim of this work is to compare the CFL and incandescent lamp in the field of life cycle assessment (LCA). The methodological framework of all the LCA techniques is based on the ISO standards 14040-14043. The life cycle analysis is performed using the Gabi4 software in order to compare environmental impacts of the $15 \mathrm{~W} \mathrm{CFL}$ and $60 \mathrm{~W}$ incandescent lamps providing similar amount of light (800-850 lumens). The functional unit is selected according to the operation time of 10.000 hours. All the materials, energy use and pollutant emissions to the environment from each process were analyzed. The environmental impact was estimated for the 6 environmental impact categories: potentials of Abiotic Depletion, Acidification, Eutrophication, Global Warming, Ozone Layer Depletion, Photochemical Ozone Creation. The results showed that during the operation period of 10,000 hours of each kind of lamp, the negative impact on the environment of the product is highest in the use phase due to electricity use. According to the analyzed environmental impact categories and from an environmental point of view the CFL is more appropriate source of light than incandescent bulb mainly because of their more efficient use of electricity and due to longer exploitation time.
\end{abstract} cycle.

Keywords: Life cycle assessment (LCA), compact fluorescent lamp (CFL), incandescent lamp, life

\section{Introduction}

The life cycle assessment (LCA) is a framework and methodology for the assessment of the environmental impact of the products or processes. It is characterized by the analysis of cumulative environmental impacts over the extended system boundaries. While a conventional environmental assessment techniques focus only on either manufacturing processes or end-of-life disposal (or reuse), the LCA considers the life cycle of a system, or the entire chain of events and activities that are necessary to support the product or process. This is often called the "cradle-to-grave" approach, and has the obvious advantage of revealing potentially significant but "hidden" environmental impacts (e.g. the biggest environmental impact of rice is the water usage necessary to grow the crop. Inefficient irrigation methods can use more water than is necessary. Depending on the production location, the transportation can also have a large impact).

The life cycle concept thus gives a more accurate picture of the environmental impacts than the conventional techniques; it evolved over the last three decades from a relatively vague framework for conducting assessments, into a rigorous set of internationally standardized guidelines (Raymond 2008).

Presently there is a widespread trend towards wholesale replacement of the incandescent bulbs with compact fluorescent light (CFL) bulbs. Certain nations and regions have implemented or are considering bans on the incandescent lighting. While it is clear that during the use, the CFLs consume less electricity than the traditional incandescent bulbs, it is not so evident to what extent the increased 
manufacturing burden offsets the energy savings during the use. This analysis is especially pertinent due to the growing global concerns over the greenhouse gasses, for which migration of $\mathrm{CO}_{2}$ emissions from one region to another is of no environmental benefit (Tosenstock 2007). The same purpose of the LCA is to discuss the lifetime of atmospheric emissions, solid waste processing from manufacture, use and disposal of the CFL compared with the incandescent lamp.

The greatest advantage of the CFLs is its energy efficiency during use, with much less energy lost to heat. The CFLs typically convert about $45 \%$ of the electricity to visible light, whereas the incandescent bulbs only about $10 \%$ (Tosenstock 2007). Since the CFL's take advantage of both passive and semiconducting electronic components, they involve complex manufacturing flows and induce greater energy demand. These results were summarized by Hitesh Soneji (2008).

This study intends to evaluate and compare the environmental impact of the CFL and incandescent lamp using the measures of LCA.

\section{Methodology}

The LCA is a "cradle-to-grave" approach for the assessment of industrial systems. The "cradle-tograve" approach begins with the gathering of raw materials from the earth to create the product and ends at the point when all the materials are returned to the earth. The LCA evaluates all stages of a product's life from the perspective that they are interdependent, meaning that one operation leads to the next. The LCA enables the estimation of the cumulative environmental impacts resulting from the all stages in the product life cycle, often including the impacts not considered in more traditional analyses (Fig. 1) (Curran 2006).

Production of Raw Material. The raw materials come from many different sources, and obtaining each one of those materials involves a different series of inputs, outputs and processes, each of which has an impact on the environment. In order to examine how much the raw material impacts the environment, it is necessary to account for all the inputs and outputs throughout the life cycle of the raw material extraction (Jensen 1997). Many products are made up of a multiple components, and nearly all require some form of a packaging material in order to protect them during the transit to the final customer. This first stage of the life cycle accounts for the emissions and resource usage associated with the production of the various raw materials that go into the final product and their transportation to the manufacturing point. If it is known that a component or item of the packaging is made from the recycled materials, it is acceptable to adjust the impacts associated with its production accordingly.

Manufacture. The manufacturing phase takes all of the raw materials defined above, as delivered to the point of production, and accounts for the energies used and the emissions associated with fabricating the final product. For some products, the manufacturing impacts are dominated by the energy usage, while, for others, by the emissions during manufacturing that are the most important.

Distribution. The distribution phase covers the transportation of the product from its point of production to the its point of installation and use. There might be a tendency when thinking about the LCA to believe that a detailed transport model will be required. However, for many products, the transport and distribution form a small part of the overall environmental footprint. An impacts from the distribution tend to be more significant if the product needs to be refrigerated during the transit, which obviously isn't the case for an UEL (Ultra Efficient Lamp) products.

Use/Consumption. The use/consumption phase of a product is usually relatively straightforward to define, though it is important that a consistent basis is chosen against which to compare the different products. For a luminary systems, the use phase is associated with the consumption of electricity to produce the light (Scholand 2009).

End-of-Life. The final stage of the life cycle is the 'end-of-life', reflecting what happens when the things are no longer required. It is far from straightforward to define what is within and without the system boundary at the end-of-life, but some rules of thumb exist. As well as accounting for the product itself, the end-of-life phase needs to take account of an other integral components, most notably the packaging. The aspects such as the handling of transportation vehicles at their end-of-life are usually not explicitly included, as those impacts (together with, for example, the original production impacts) are rolled into the tones-kilometre impacts associated with the transportation during their service life (Zbicinski 2006, Scholand 2009).

By including the impacts throughout the product life cycle, the LCA provides a comprehensive view of the environmental aspects of the product or process and a more accurate picture of the true environmental trade-offs in the product and process selection (Michael et al. 2010).

The life cycle assessment is unique because it encompasses all the processes and environmental releases beginning with the extraction of the raw materials and the production of the energy used to create the product through the use and a final disposition of the product. When it is necessary to resolve between two or more alternatives, the LCA can help for decision-makers to compare all the major environmental impacts caused by the products, processes, or services (Curran 2006).

In order to make the assessment of the environmental impact of the CFL and incandescent lamp easier, the LCA methodology and the "GaBi" software have been used. 


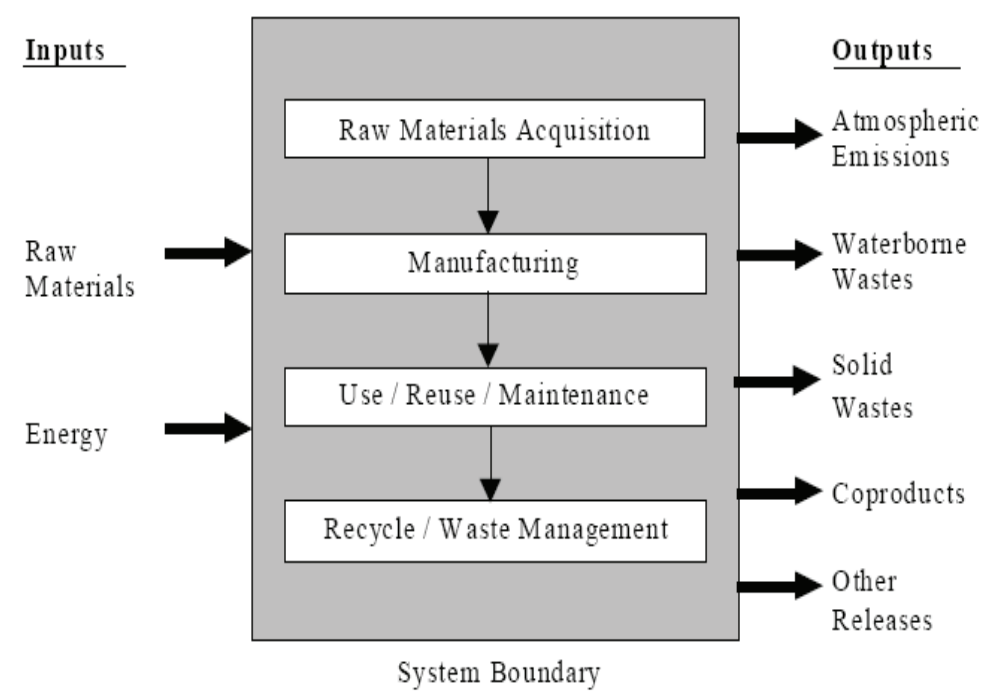

Fig.1.

The stages of the Life Cycle (Curran, 2006)

The methodological framework of all the LCA techniques is based on the ISO standards $14040-$ 14043.

A complete LCA, which is consistent with the ISO standards, consists of the four interrelated phases, (Fig. 2) (Scholand 2009):

1) The Goal Definition and Scoping - the first phase of the LCA is to specify the goal and scope of the study (Handbook for Life Cycle Assessment 2009). Define and describe the product, process or activity. Establish the context in which the assessment has to be made, identify the functional unit and system boundaries and the environmental effects to be reviewed for the assessment (Curran 2006).

2) The Inventory Analysis - the second phase is characterized by the assimilation of the data and the modeling of flows for the product under the study. The data collected and used in this phase includes all the environmental and technical quantities for an all relevant unit processes within the system boundaries (Handbook for Life Cycle Assessment 2009). Identify and quantify the usage of energy, water and materials and the releases to the environment (e.g., air emissions, solid waste disposal, waste water discharges) (Curran 2006).

3) The Impact Assessment - the third phase centers on the evaluating the contribution to the impact categories (Handbook for Life Cycle
Assessment 2009). Assess the potential human and ecological effects of the usage of energy, water, material and the environmental releases identified in the inventory analysis (Curran 2006). The impact assessment is mainly based on a classification, characterization and weighting steps. During the classification step an environmental impact categories are determined and the data of the inventory analysis are attributed to an each category. In the case of employing the "GaBi" software, the classification step is based on the CML 2001 method.

The CML method is the methodology of the Centre for Environmental Studies (CML) of the University of Leiden and focuses on a series of environmental impact categories expressed in a terms of emissions to the environment. The CML method includes the classification, characterization and normalization. The impact categories for the global warming potential and ozone layer depletion are based on the IPCC (Intergovernmental Panel on Climate Change) factors.

Under the CML 2001 method, the impacts were classified into the abiotic depletion, acidification potential, eutrophication potential, global warming potential, ozone layer depletion potential, photochemical ozone creation potential (Table 1) (Handbook for Life Cycle Assessment 2009).

Table 1.

The indicators for the selected environmental impact categories

\begin{tabular}{|c|c|}
\hline \multicolumn{2}{|l|}{ CML 2001 } \\
\hline Environmental impact category & Category indicator \\
\hline Abiotic Depletion (ADP) & {$[\mathrm{kg} \mathrm{Sb-Equiv.}]^{\mathrm{a}}$} \\
\hline Acidification Potential (AP) & [kg SO2-Equiv.] \\
\hline Eutrophication Potential (EP) & [kg Phosphate-Equiv.] \\
\hline Global Warming Potential (GWP 100 years) & [kg CO2-Equiv.] \\
\hline Ozone Layer Depletion Potential (ODP, steady state) & [kg R11-Equiv.] $^{b}$ \\
\hline Photochemical Ozone Creation Potential (POCP) & [kg Ethene-Equiv.] \\
\hline
\end{tabular}


In the previous step, the substances contributing to the impact categories were taken from the inventory table and ascribed to a certain group. However, the different substances among one group contribute differently to the impact category. During the characterization step the relative strength of the unwanted emission was evaluated and contribution to each of the environmental problems was quantified. What is needed here is a single number for the each category. The characterization was performed on the basis of environmental models, which allow us to compare the different substances contributing to the same environmental problem. This was done by applying a so-called equivalence factors. An equivalence factor indicates how many times more a given compound contributes to a problem in comparison to a chosen reference substance.

In order to obtain a single score representing the environmental impact of a product it is necessary to aggregate the data. Weighting is the step in which the different impact categories are weighted so that they can be compared among themselves, i.e. the relative importance of the effects is assessed (Zbicinski 2006).

In the comparative analysis the prime goal is to find out which one of the products fulfilling the same function is the best option for the environment (Sholand 2009).

4) The Interpretation - all the three previous phases are shown with links to the interpretation (Curran 2006).

This stage is necessary in order to evaluate the results of the inventory analysis and impact assessment, to select the preferred product, process or service with a clear understanding of the uncertainty and the assumptions used to generate the results (Curran 2006).

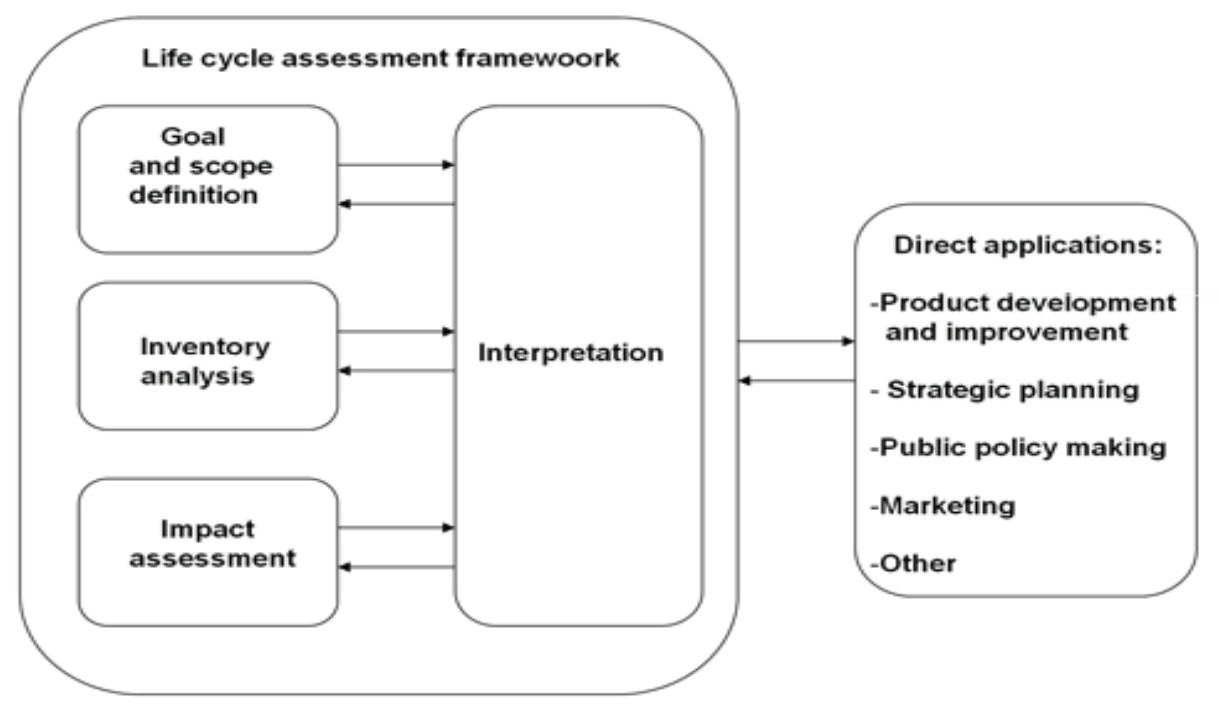

Fig.2. The phases of the LCA (Karaliunaite 2002)

\section{Results}

\subsection{Goal definition and scope}

The main goal of this research was to estimate and compare the environmental impact of the CFL and incandescent lamp, using the measures of the life cycle assessment.

The tasks of the research were to identify the most significant environmental aspects of the different kind of lamps in the production, use and disposal stages.

\subsection{The Functional unit and system boundaries}

The functional unit is a light source which operation time is 10.000 hours. This operation time is consistent with the one $15 \mathrm{~W}$ CFL lamp and ten $60 \mathrm{~W}$ incandescent lamps. All the information about inputs and outputs was associated with the functional unit.
The life cycle of lamps includes many steps, starting from the material extraction and ending with the disposal to a landfill. In this study the LCA analysis of the CFL and incandescent lamp includes all stages of the life cycle: production, use, disposal, except distribution. The distribution stage of the lamps (products) has not been characterized, because the distances from the factory to a warehouse (shops) are very different.

The maintenance of the buildings, equipment is not included in the analysis, because the impact of the power consumption on the environment is very low, compared with the quantity of the output, produced during the lifetime of the buildings and equipment (Michaud 2008).

There is always other factor in the industrial structures such as wastewater, energy use for air conditioning, emissions from vehicle, which may contribute to the environmental impact. In most cases the effects of the mentioned factors on the environment are quite low consequently they were not introduced in the LCA analysis. 
In our evaluation it was analyzed assuming that both kinds of lamps are simply thrown to the landfill at the end of life. In the future this LCA will be extended in the field of comparison of different treatment technologies of such wastes.

\subsection{Inventory analysis}

The inventory analysis is the core of the LCA and is a common feature of any LCA. During this phase all flows of the materials, energy and all the waste streams related with the functional unit were identified and quantified. The final result of the inventory analysis is an inventory table (table 2.).

The data for the inventory analysis were collected by analyzing the paper of Ramroth (2008).

Table 2. The data of the inventory analysis of the functional unit

\begin{tabular}{|c|c|c|c|}
\hline Intermediate flow & Unit & $\begin{array}{l}\text { The data of functional unit of } \\
\text { compact fluorescent lamp }\end{array}$ & $\begin{array}{l}\text { The data of functional unit } \\
\text { of incandescent light bulb }\end{array}$ \\
\hline \multicolumn{4}{|l|}{ Production } \\
\hline \multicolumn{4}{|l|}{ Materials } \\
\hline Glass & $\mathrm{g}$ & 22,35 & 260,5 \\
\hline Phosphor & $\mathrm{g}$ & 0,95 & 0 \\
\hline Silica & $\mathrm{g}$ & 0 & 8,1 \\
\hline Tinplate & $\mathrm{g}$ & 2,35 & 17,1 \\
\hline Copper & $\mathrm{g}$ & 23,57 & 11,7 \\
\hline Lead & $\mathrm{g}$ & 1,02 & 10,6 \\
\hline Black glass & $\mathrm{g}$ & 4,97 & 33,3 \\
\hline PET & $\mathrm{g}$ & 12,83 & 0 \\
\hline Platinum & $\mathrm{g}$ & 4,36 & 1,1 \\
\hline Glue & $\mathrm{g}$ & 2,73 & 15,9 \\
\hline Argon & $\mathrm{g}$ & 0,017 & 0,74 \\
\hline Mercury & $\mathrm{g}$ & 0,003 & 0 \\
\hline Nitrogen & $\mathrm{g}$ & 0 & 0,04 \\
\hline Cardboard & $\mathrm{g}$ & 26,03 & 231,8 \\
\hline Total - light bulb: & $\mathrm{g}$ & 105,18 & 590,88 \\
\hline \multicolumn{4}{|l|}{ Energy } \\
\hline Transport (diesel fuel) & $\mathrm{kWh}$ & 130 & 600 \\
\hline Heat (diesel fuel) & $\mathrm{tkm}$ & 0,001 & 0,012 \\
\hline Electricity & $\mathrm{kWh}$ & 0,224 & 0,08 \\
\hline \multicolumn{4}{|l|}{ Use } \\
\hline \multicolumn{4}{|l|}{ Energy } \\
\hline Electricity & $\mathrm{kWh}$ & 130 & 600 \\
\hline Transport - waste (diesel fuel) & $\mathrm{tkm}$ & 0,001 & 0,012 \\
\hline \multicolumn{4}{|l|}{ Waste (packaging) } \\
\hline Cardboard & $\mathrm{g}$ & 26,03 & 231,8 \\
\hline \multicolumn{4}{|l|}{ End of life } \\
\hline \multicolumn{4}{|l|}{ Energy } \\
\hline Transport (diesel fuel) & tkm & 0,003 & 0,016 \\
\hline \multicolumn{4}{|l|}{ Waste (light bulbs) } \\
\hline Plastic base (landfilled) & $\mathrm{g}$ & 12,83 & 0 \\
\hline Other landfilled components & $\mathrm{g}$ & 65,957 & 354,78 \\
\hline \multicolumn{4}{|l|}{ Emission } \\
\hline Mercury (air) & $\mathrm{g}$ & 0,003 & 0 \\
\hline Lead (water) & $\mathrm{g}$ & 0,36 & 4,3 \\
\hline
\end{tabular}

\subsection{Impact Assessment}

Through the LCA analysis the greenhouse-gas emissions related with the production, use, and disposal of functional unit were identified. The environmental impact category of the Global Warming Potential (GWP) was used to convert several greenhouse-gas emission estimates into a common, comparable unit. A multiplier is assigned to the each greenhouse gas based on the impact it has on the global warming over the course of 100 years on a scale normalized to the impact one atom of the carbon dioxide $\left(\mathrm{CO}_{2}\right)$ has over 100 years. These units are called the carbon dioxide-equivalents, or $\mathrm{CO}_{2}$-equiv (Horn 2006). 


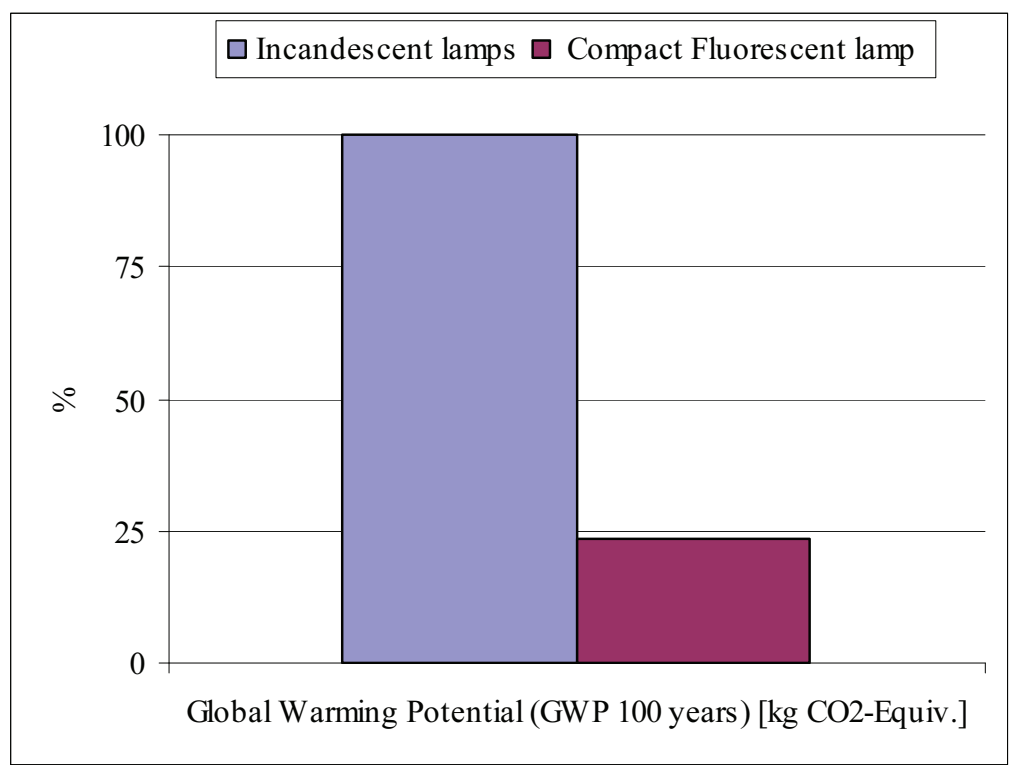

Fig. 3.

The characterization of the functional unit of the each kind of lamp

During the operation time of the 10,000 hours, the CFL would produce about 25 percent $(916,97 \mathrm{~kg}$ $\mathrm{CO}_{2}$-equiv) of the greenhouse gases that would be emitted by the incandescent bulbs over the same operation time (3876,03 $\mathrm{kg} \mathrm{CO}_{2}$-equiv.) (Fig. 3).

It is helpful to assign the $\mathrm{CO}_{2}$-equiv. emissions to a various processes in order to determine which emissions are the major polluters.

For an incandescent lamp, almost all of the greenhouse-gas emissions attributable to the lamp occur during the use phase. In fact, over the $99 \%$
(3868,70 $\mathrm{kg} \mathrm{CO}_{2}$-equiv.) come from the generation of the electricity required to power the lamp at the users' sites, while the other $-\sim 1 \%\left(7,23 \mathrm{~kg} \mathrm{CO}_{2}\right.$-equiv. $)$ is attributable to the production phase, and $0,003 \%$ $(0,11 \mathrm{~kg} \mathrm{CO}$-equiv. $)$ of the emissions are generated during the disposal phase. In the case of the CFL, 91 $\%$ of the $\mathrm{CO}_{2}$-equiv. (838,21 $\mathrm{kg} \quad \mathrm{CO}_{2}$-equiv.) emissions are generated during the use phase, while approximately $1 \%\left(5,80 \mathrm{~kg} \mathrm{CO}_{2}\right.$-equiv.) occur during the production and $8 \%\left(72,96 \mathrm{~kg} \mathrm{CO}_{2}\right.$-equiv. $)$ emission during the disposal phases (Fig. 4).

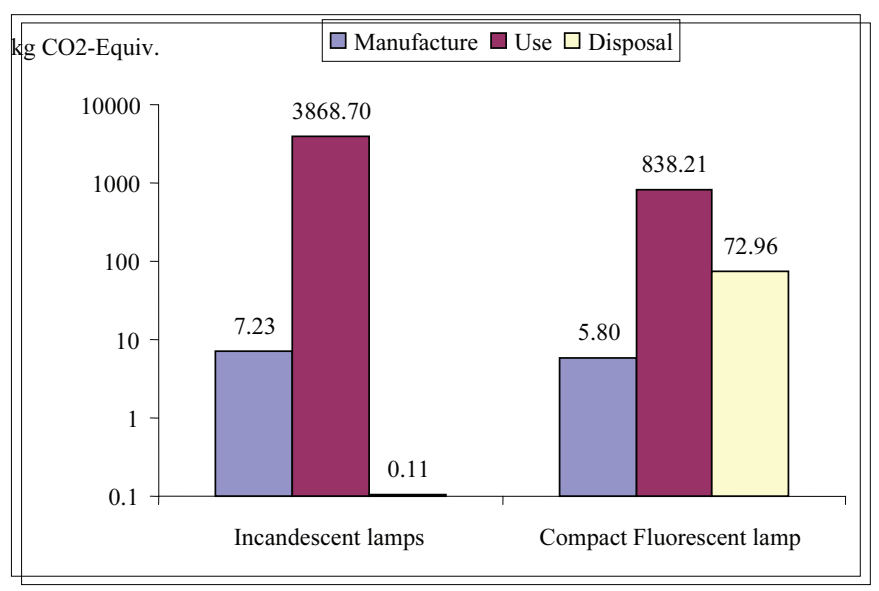

Fig. 4. The characterization of the functional unit according to the environmental impact category of the GWP during the Life Cycle

Figure 5 shows the ratio of the resulting environmental impact of both kind of lamps using criteria under the method of CML 2001.

The Ozone Layer Depletion Potential (ODP, steady state) [kg R11-Equiv.] is not submitted, because the calculated impact of the both type of bulbs on the ozone layer depletion is zero. The Global Warming Potential (GWP) was discussed in the Fig.3 and Fig.4. In comparison the AP, POCP and EP potentials, the latter increases in the case of CFL and decreases in the case of incandescent lamp use. 


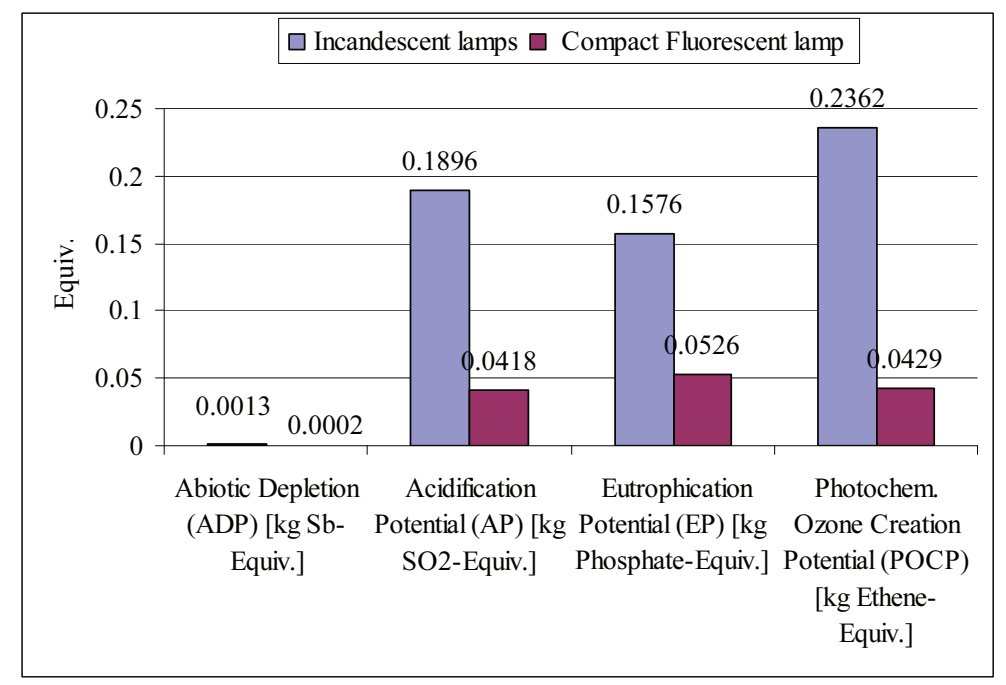

Fig. 5. The environmental impact of the functional unit according to the used method of CML 2001

\section{Conclusions}

The compact fluorescent lamp is a significantly better source of the light from an environmental point of view than incandescent lamps mainly because of their more efficient use of electricity. The key factor for all conclusions is that the CFL can use up to onefourth of electricity of incandescent bulb of equivalent brightness and the operation time of the CFL is much longer than the incandescent lamp.

- The results of LCA showed that during the production phase ten incandescent bulbs exerted higher levels of the environmental impact that is associated with the damage to human health, ecosystem quality, and resource depletion, compared to the one compact fluorescent lamp.

- The results of analysis revealed that the one compact fluorescent lamp would produce four times less of the greenhouse gases that would be emitted by the ten incandescent bulbs over the same operation period.

- It was identified that the greatest negative impact of both kinds of lamps is in the use phase, when electricity for the running of the lamp is used.

- $\quad$ The Global Warming Potential of both sources of light is much higher compared to the Abiotic Depletion, Acidification Potentials, Eutrophication Potential, Global Warming Potential, Photochemical and Ozone Creation Potentials.

\section{References}

Curran, M. A. 2006. Life cycle assessment: principles and practice. Scientific Applications International Corporation (SAIC). [2012-02-29]:

http://www.epa.gov/nrmrl/std/lca/pdfs/chapter1_frontmatter _lca101.pdf

Handbook for Life Cycle Assessment (LCA) Using the GaBi Education Software Package. 2009. [2012-02-28]: http://tutorials.gabi-

software.com/tutorial1/GaBi_Education_Handbook.pdf

Jensen, A. A., Hoffman, L., Moller, B. T., Schmidt, A. 1997. Life Cycle Assessment. A guide to approaches, experiences and information sources. Environmental Issues Series no. 6. From European Environment Agency, Reports (1997).

Karaliūnaitė, I., Žaliauskienė, A., Bergqvist, P-A. Life Cycle Assessment for Comparing Different Leather Treatment Technologies. Environmental Research, Engineering and Management, 2002 Vol. 22, No. 4. pp. 1117. Kaunas, Technologija. ISSN 1392-1649.

Michael, E., Chadwick, P., Jay Parsons, G., Sayavong, B. 2010. Evaluation of Closed-containment Technologies for Saltwater Salmon Aquaculture. Canada, National Research Council of Canada, p. 160. pp. 132-133. ISBN 978-0-660-19968-9.

Michaud, R., Belely, C., Clement, E., Margni, M., SAMSON, R. 2008. Comparative life cycle assessment of light bulbs: Incandescents and Compact Fluorescents. [2012-02-28]:

http://www.ciraig.org/pdf/LCA_light_bulbs_final_summary .pdf

Parsons, D. The environmental impact of compact fluorescent lamps and incandescent lamps for Australian conditions. The Environmental Engineer, 2006,Vol. 7. pp. 8-14.

Raymond, R. T., Alvin, B. C. 2008. Environmental Life-Cycle Assessment: A Tool for Public and Corporate Policy Development. [2012-02-28] http://www.imamu.edu.sa/topics/IT/IT\%206/A\%20Tool\%2 0for $\% 20$ Public $\% 20$ and $\% 20$ Corporate $\% 20$ Policy $\% 20$ Devel opment.pdf

Ramroth, L. 2008. Comparison of Life-Cycle Analyses of Compact Fluorescent and Incandescent Lamps Based on Rated Life of Compact Fluorescent Lamp. From the Reports of Rocky Mountain Institute 2008, [2012-0228]:

http://unina.stidue.net/Politecnico\%20di\%20Milano/Elettro 
nica\%20ed\%20Informazione/Paco.Melia/tesi/lampade/C0802_CFL_LCA.pdf

Scholand, M. 2009. Life Cycle Assessment of UltraEfficient Lamps. From the Reports of Department for Environment, Food and Rural Affairs 2009.

Soneji, H. 2008. Life Cycle Energy Comparison Of Compact Fluorescent and Incandescent Light Bulbs. Sustainability Science Paper. [2012-02-28]: http://www.djluv.com/career/research/Soneji-CFL-LCASustSciPaper.pdf

Tosenstock, S. 2007. Another perspective. Electric Perspectives, 2007, Vol. 32, No. 5. pp. 100-105

Zbicinski, I., Stavenuiter, J., Kozlowska, B., Coevering, H. 2006. Product Design and Life Cycle Assessment. Baltic University Press, Uppsala, p.312. pp. 17-28. ISBN 91-975526-2-3
MSc. Erika Elijošiutè - PhD Student at Kaunas

University of Technology, Department of

Environmental Engineering.

Main research are: Hazardous waste treatment and management.

Addres: $\quad$ Kaunas, Radvilènų av. 19

Tel.: +37037300182

E-mail: erika.elijosiute@ktu.lt

Bc. Jolita Balciukevičiūtė - master student at Kaunas University of Technology, Department of Environmental Engineering.

Main research are: Hazardous waste treatment and management, Life cycle assessment.

Addres: Kaunas, Radvilenų av. 19

Tel.: $\quad+37062858248$

E-mail: $\quad$ j.balciukeviciute@gmail.com

Prof. dr. Gintaras Denafas - at Kaunas University of Technology, Department of Environmental Engineering.

Main research are: Waste management,

Environmental impact assessment.

Addres: Kaunas, Radvilènu av. 19

Tel.: $\quad$ +370 37300180

E-mail: $\quad$ gintaras.denafas@ktu.lt

\title{
Kompaktinių fluorescencinių ir kaitrinių lempučių būvio ciklo lyginamasis vertinimas
}

\author{
Erika Elijošiutė, Jolita Balciukevičiūtè, Gintaras Denafas
}

Aplinkos inžinerijos katedra, Kauno technologijos universitetas

(gauta 2012 m. rugsejjo mèn., priimta spaudai 2012 m. rugsëjo mèn.)

Nustatyta, kad bendros energijos sąnaudos komerciniams pastatams ir pramonės įmonėms apšviesti atitinkamai yra $20-45$ proc. ir 3-10 proc. Šiuo atveju energiją taupančias lemputes, tokias kaip kompaktinès fluorescencinės lemputès (toliau - KFL), naudoti priimtiniau, nes šios sunaudoja mažiau elektros energijos nei plačiai paplitusios kaitrinès lemputè - tik 20 proc. Šio darbo tikslas - palyginti KFL su kaitrinėmis lemputėmis naudojant būvio ciklo vertinimą, kurio metodika paprastai remiasi ISO standartais 14040-14043.

Atliekant būvio ciklo analizę Gabi4 programa, buvo lyginamos $15 \mathrm{~W}$ KFL ir $60 \mathrm{~W}$ kaitrinès lemputès, kurioms būdingas vienodas apšviestumas (800-850 liumenu). Atitinkamas funkcinis vienetas buvo parinktas 10000 naudojimo valandų. Abiem lempų naudojimo procesams vykdyti buvo išanalizuoti medžiagų ir energijos sąnaudos bei teršalų išmetimai ị aplinką.

Buvo nustatytas šešių kategorijų poveikis aplinkai. Tai: abiotinis išteklių sunaudojimas, rūgštėjimo potencialas, eutrofikacijos potencialas, visuotinio atšilimo potencialas, ozono sluoksnio nykimo potencialas, fotocheminio ozono susidarymo potencialas. Rezultatai parodè, kad kiekvienam lempučių tipui 10000 valandų naudojimo laikotarpiu didžiausias poveikis aplinkai yra būdingas elektros energijos naudojimo fazėje. Vertintų poveikio aplinkai kategorijų ir poveikio aplinkai požiūriu matyti, kad KFL, lyginant jas su kaitrinėmis lemputèmis, labiau tinkamas šviesos šaltinis dèl taupesnio elektros energijos naudojimo ir ilgesnio eksploatacijos laiko. 